\title{
Subgroups in Agile and Traditional IT Project Teams
}

\author{
Christoph Pflügler \\ Technical University of Munich \\ Chair for Information Systems \\ christoph.pfluegler@in.tum.de
}

\author{
Manuel Wiesche \\ Technical University of Munich \\ Chair for Information Systems \\ wiesche@in.tum.de
}

\author{
Helmut Krcmar \\ Technical University of Munich \\ Chair for Information Systems \\ krcmar@in.tum.de
}

\begin{abstract}
This paper analyzes the formation of subgroups within project teams that apply agile methods and teams that apply traditional methods. Subgroups form based on faultlines, which are dividing lines regarding attributes of diversity of the team members. We conduct case studies of two agile projects and two projects with a traditional approach. We find that the formation of subgroups differs between the two methods. Task assignment is the dominant factor that leads to the formation of subgroups in traditional methods, whereas previous ties between team members is the dominant factor in agile projects. In addition, location and language lead to the formation of subgroups in both methods. Our analysis is exploratory and our data is limited to four teams. We contribute to the literature on team formation and groups in IT project teams and show that research should consider subgroups and potential consequences when examining agile and traditional software development methods.
\end{abstract}

\section{Introduction}

The success of IT projects depends, among other things, on the skills of the team members $[1,2]$. However, the selection and combination of different team members is an ongoing challenge [1, 3]. Previous studies have found that heterogeneity among the team members increases creativity $[4,5]$. At the same time, the heterogeneity of team members' attributes can also lead to the formation of subgroups within the project team [6, 7]. A subgroup is a subset of team members that is characterized by a unique form of a certain attribute (e.g. age, skill or status) [7].

Especially IT projects that apply agile methods, like Scrum or Extreme Programming demand team heterogeneity and foster close collaboration [8]. On the contrary, teams that follow traditional project management methods are selected based on their capabilities to conduct a pre-planned task [9]. Due to these differences in the way the team collaborates and the team conducts tasks, the formation of subgroups is supposed to differ between projects with agile methods and projects with traditional methods. Practitioners should consider the formation of subgroups when applying these project management methods, because they influence the performance of the project [10-13]. Additionally, if they are aware of the possible formation of subgroups, they can initiate actions that hinder the formation, like staffing and managing the project differently.

However, it remains unclear how subgroups form in IT projects with agile and traditional methods. Due to the differences in team composition and conducting tasks, different types of subgroups form in agile and traditional IT projects, based on faultlines, which are dividing lines that are based on attributes of diversity of team members [7, 14]. For instance, agile methods emphasize values like commitment, openness and respect [15]. This creates a different form of exchange between the team members [16], which in turn influences the formation of subgroups. As it remains unclear how subgroups form under agile methods and under traditional methods, it is difficult to develop actions that hinder the formation or weaken the influence of the subgroup. To address this gap, we seek to answer the following research question: Which factors lead to the formation of subgroups in agile and traditional project management methods?

We chose an exploratory case study design to answer this question. We analyze four IT development projects. Two projects have employed an agile method and two projects followed a traditional approach.

We find that there are differences in the formation of subgroups between agile methods and traditional methods. The primary factor that leads to the formation of subgroups in traditional projects is the task assignment. Agile teams are characterized by subgroups that are formed due to ties between team members that know each other from previous interactions. Additionally, we find that no matter if an agile method or a traditional method has been chosen, different locations and languages lead to the formation of very dominant subgroups. 
This paper is structured as followed. First, we present background information on faultlines and subgroups as well as on agile and traditional project management methods. This is followed by a presentation of the chosen research method. Then, we present the results and report on the found subgroups in agile methods and traditional methods. Finally, the theoretical and practical implications as well as limitations and possible future research are discussed. The paper ends with a short conclusion.

\section{Theoretical Background}

\subsection{Faultlines and Subgroups}

A subgroup is a subset of members of a work team, which is characterized by a unique interdependence that distinguishes the subset from other members of the team [7]. Subgroups are formed based on faultlines, hypothetical dividing lines, which split a team into multiple, homogeneous subgroups [14]. Faultlines are based on individual attributes, like education, gender or work experience. Team members, who share one or more of these characteristics, bond with each other and thus create a subgroup [17]. Previous literature has already identified possible faultlines (see table 1).

Table 1. Faultlines In Previous Literature

\begin{tabular}{|l|l|}
\hline \multicolumn{1}{|c|}{ Faultline } & \multicolumn{1}{|c|}{ Description } \\
\hline Demographic & $\begin{array}{l}\text { Identity-based factors of team members like age, } \\
\text { gender, race or religion [14] }\end{array}$ \\
\hline Geographic & $\begin{array}{l}\text { Factors related to the location or the distance } \\
\text { between the team members [18] }\end{array}$ \\
\hline $\begin{array}{l}\text { Language/ } \\
\text { Culture }\end{array}$ & $\begin{array}{l}\text { Factors, like language, nationality or culture. } \\
\text { Often related to geographic factors, but not } \\
\text { necessarily the same [14, 19-21] }\end{array}$ \\
\hline Personality & $\begin{array}{l}\text { Factors that refer to the personality of the team } \\
\text { members, like conscientiousness, emotional } \\
\text { stability, attitudes, beliefs, values or cognitive } \\
\text { style [22-24] }\end{array}$ \\
\hline $\begin{array}{l}\text { Employer } \\
\text { related }\end{array}$ & $\begin{array}{l}\text { Employer related factors, like tenure, function, } \\
\text { pay, status or decision power [7, 14, 24, 25] }\end{array}$ \\
\hline Knowledge & $\begin{array}{l}\text { Factors like education or work experience, that } \\
\text { related to the knowledge of the team members [7] }\end{array}$ \\
\hline
\end{tabular}

Within a team there might be several different faultlines, but not all of them are activated and lead to the formation of a subgroup [26].

Literature distinguishes three types of subgroups [7]. First, members of identity-based subgroups are characterized by the same characters or share similar values [27]. Second, knowledge-based subgroups are formed based on technical language [28]. Members of this type of subgroup often share information or use this form of exchange to solve problems and tasks together [7]. Third, resource-based subgroups are based on the idea of group conflict theory [29] as well as on theories of inequality and organizational ranks [30]. Members of this type of subgroup differentiate according to the ability to claim resources, such as decision power [7]. Therefore, resource-based subgroups often form based on the hierarchical level.

The effects of subgroups have been studied intensively, but the empirical results differ. While some studies suggest that subgroups also have positive effects for team members [10, 12], the majority highlights their negative consequences. In general, any type of faultline may have both, positive and negative impacts [13]. Positive effects of subgroups are mainly found related to knowledge-based subgroups [10, 12]. They have the advantage that they bring different forms of knowledge into one team [12].

Negative consequences are mostly related to identity-based and resource-based subgroups. Identitybased subgroups may lead to conflicts in the whole team, caused by ethnocentrism [31], especially when there are two strong subgroups of this kind in one team, which work against each other [12]. Resourcebased subgroups in teams may lead to an asymmetry in perception of fairness and power centralization [7] which disturbs the common decision making process [32]. In general, subgroups may cause an interruption of the knowledge flow within the team, as subgroup members communicate primarily with other members of the same subgroups [11]. Another negative aspect is social loafing of individuals, which happens primarily in larger subgroups [33].

Especially difficult situations and crises foster subgroups and reinforce the barriers between individuals in the project team [34]. When these negative consequences occur in software project teams, it may have serious influence on the project success.

\subsection{Agile and Traditional Project Management Methods}

Agile methods gained popularity in recent years [8]. There are several different agile methods, like Scrum, Kanban and Extreme Programming, but Scrum is by far the most used one [35]. These approaches focus on the social nature of software development [16]. Values like commitment, openness and respect form the footing of all agile methods and lead to a higher perception of job satisfaction within software development teams [15]. Furthermore, additional factors like team awareness and team involvement foster cohesion within the team [16].

An important principle of agile methods is the selfmanagement of the team [36]. Flat hierarchies and the 
possibility to decide how to accomplish work are fundamental aspects, which give the team higher responsibility in its work life and rises again the satisfaction level [37]. The basis for self-managing teams is a shared-decision making process, which demands respect and trust within the whole team [38].

Communication plays a special role within agile principles [39]. Agile methods trust in face-to-face communication, whenever it is possible [40] and see continuously exchange between team members, managers and customers as an important influence factor for project success. Frequent communication between team members supports not only performance and quality [41], but also promotes knowledge sharing in project teams [42].

Traditional methods are different from agile methods. They have a long tradition in IT development projects and are currently still broadly used, especially in the manufacturing industry [35, 43]. Traditional methods are characterized by a pre-planning stage that is followed by the execution, which makes them less flexible in comparison to agile methods [9, 43]. Additionally, unlike agile methods, they have a clear hierarchy within the team [9]. The collaboration is less close than in an agile project team. Daily meetings are not part of the methodology like in agile methods. As the task assignment is stable in traditional methods, the team members work together with the same few persons for most of the project time [9].

\subsection{Subgroups within Agile and Traditional Projects}

The previously described differences between agile methods and traditional methods should have different influences on the activation of faultlines and therefore on the formation of subgroups. Up to now, literature has only dealt with distributed agile teams and therefore has limited the perspective to geographical distance [44, 45]. First, the collaboration differs between projects with an agile and a traditional method [9]. The team members work much closer together under agile methods. Second, the fix task assignment in traditional methods leads more stable structured within the team [9]. Therefore, the same team members work always together whereas different ones work together in agile methods.

\subsection{Distributed Teams as Example for Subgroups in Software Development}

There is already extensive literature on virtual and distributed teams [46, 47]. However, this literature mostly lacks of consideration of subgroups, although geographical distribution is a factor that is likely to lead to the formation of subgroups [46]. The faultline factors in the case of virtual teams are location and language [18, 46]. Cramton and Hinds [31] theoretically expended the faultine model of Lau and Murnighan [14] to virtual teams, but did not empirically test their model. An exception is Polzer, Crisp [18] that analyse the activation of faultlines and subgroups in geographically dispersed teams. They found that subgroups form and that conflict is heightened and trust is decreased between the geographically dispersed subgroups. Another exception is O'Leary and Mortensen [48] that found that geographically based subgroups weaken team identification, lead to less effective transactive memory and increase team conflict.

As this brief overview of literature on virtual and distributed teams shows, most studies miss a consideration of subgroup theories. There are a few exceptions, but none of these studies have been conducted in the IT domain or consider also other types of subgroups, like identity-based or knowledgebased subgroups.

\section{Research Method}

To analyze factors that lead to the formation of subgroups, a qualitative design has been chosen. We decided to conduct a case study to answer our exploratory research question as it allows us to investigate phenomena in depth in its real-world context [49]. We explored the formation of subgroups in two agile IT projects and two traditional IT projects.

\subsection{Case Selection}

Table 2 shows the description of the selected cases. In general, we selected cases with a certain number of team member in order to increase the likeliness of finding subgroups [12].

Teams 1 and 2 are projects with an agile method and were conducted in a German IT company. Teams 3 and 4 are projects with a traditional method and were conducted in a German financial service company.

\subsection{Data Collection and Analysis}

Table 2 shows the number of interviews that were conducted in the four analyzed teams. In Team 1 nearly half of the team has been interviewed. More than half of the team members were interviewed in Teams 2 and 3. In Team 4 only about a quarter of the team members were interviewed. Although not all team members were interviewed, we still believe to have gotten thorough insights in all of the four teams. 
We used grounded theory coding techniques to analyze the data and develop the faultline categories as introduced in the results section [50]. We based the coding categories on factors that could be possible faultlines within the project teams. The atlas.ti software package was used to support coding and analysis.

Table 2. Selected Cases and Interviews

\begin{tabular}{|c|l|c|c|c|c|}
\hline & & & & \\
\hline 1 & $\begin{array}{l}\text { Development } \\
\text { of a software package } \\
\text { concerning insurance }\end{array}$ & 12 & 1 & Scrum & 5 \\
\hline 2 & $\begin{array}{l}\text { Development of a } \\
\text { business process } \\
\text { management software }\end{array}$ & 19 & 3 & Scrum & 12 \\
\hline 3 & $\begin{array}{l}\text { Quality management of IT } \\
\text { processes }\end{array}$ & 15 & 2 & $\begin{array}{l}\text { Tradi- } \\
\text { tional }\end{array}$ & 8 \\
\hline 4 & $\begin{array}{l}\text { Management of IT } \\
\text { Change Requests }\end{array}$ & 12 & 2 & $\begin{array}{l}\text { Tradi- } \\
\text { tional }\end{array}$ & 3 \\
\hline
\end{tabular}

\section{Results}

\subsection{Agile Method}

The two agile teams were well-established, selfmanaging teams with motivated team members with a good reputation and company record of accomplishment in ISD projects. Both teams applied Scrum as agile method. We identified several faultlines and activated subgroups in each of the two teams. They are reported in table 3 .

Our results suggest that demographic faultlines like age and gender are not activated. Team 1 and 2 only had two females respectively and therefore, the formation of a gender based subgroup is unlikely. An age based subgroup is not formed, because the team members in the two agile teams have a quite similar age between 20 and 40 years.

Knowledge and education related faultlines are not activated, because experts form groups only for the discussion of a certain topic and then dissolve again. Therefore, not stable subgroup is formed.

A faultline based on functions within the team has not been activated due to the generalist-approach of agile methods, where only the roles team member, scrum master and product owner exist. However, we found that in one team the product owner has been excluded from the retrospective because of his role. He perceived himself as ostracized.
Table 3. Theoretical and activated Faultlines

\begin{tabular}{|l|l|l|l|}
\hline & an & & \\
\hline Age & $\begin{array}{l}\text { Team members were in a } \\
\text { similar age group. }\end{array}$ & & Little variance \\
\hline Gender & $\begin{array}{l}\text { Only small share of team } \\
\text { members was female }\end{array}$ & & Not many females \\
\hline $\begin{array}{l}\text { Know- } \\
\text { ledge / } \\
\text { education }\end{array}$ & $\begin{array}{l}\text { Experts assemble in groups, } \\
\text { but only for the discussion } \\
\text { of a topic and then separate } \\
\text { again }\end{array}$ & $\begin{array}{l}\text { Changing faultines } \\
\text { over time based on } \\
\text { user stories are not } \\
\text { stable }\end{array}$ \\
\hline Function & $\begin{array}{l}\text { Generalist-approach } \\
\text { reduced number of roles, } \\
\text { but product owner differed. }\end{array}$ & $\begin{array}{l}\text { Product owner was } \\
\text { the only one with a } \\
\text { different role }\end{array}$ \\
\hline $\begin{array}{l}\text { Previous } \\
\text { ties }\end{array}$ & $\begin{array}{l}\text { Several team members had } \\
\text { prior work (and } \\
\text { educational) experience } \\
\text { together. }\end{array}$ & $\mathrm{X}$ & $\begin{array}{l}\text { The self-managed } \\
\text { character makes it } \\
\text { possible that the } \\
\text { faultline is activated }\end{array}$ \\
\hline $\begin{array}{l}\text { Task / } \\
\text { goal }\end{array}$ & $\begin{array}{l}\text { Continuously changing } \\
\text { tasks and therefore goals for } \\
\text { each iteration. }\end{array}$ & $\begin{array}{l}\text { Task-based } \\
\text { subgroups are only } \\
\text { temporary and not } \\
\text { persistent }\end{array}$ \\
\hline $\begin{array}{l}\text { Geo- } \\
\text { graphical } \\
\text { distance }\end{array}$ & $\begin{array}{l}\text { Developers work in two } \\
\text { different offices in different } \\
\text { countries. }\end{array}$ & $\mathrm{X}$ & $\begin{array}{l}\text { Informal contacts } \\
\text { are not possible }\end{array}$ \\
\hline Language & $\begin{array}{l}\text { Language in country A as } \\
\text { project language, non- } \\
\text { native speaking developers } \\
\text { in country B. }\end{array}$ & $\mathrm{X}$ & $\begin{array}{l}\text { Language barrier } \\
\text { makes } \\
\text { communication } \\
\text { difficult }\end{array}$ \\
\hline
\end{tabular}

Due to the usage of user stories in agile methods that are carried out by different combinations of team members in each iteration, only temporal subgroups form for the time a user story is carried out. They then dissolve again right after finishing the user story.

In the following, we describe the most dominant subgroups that were formed due to activated faultlines.

In team 2, the most dominant subgroup was formed due to location- and language-based faultlines. Eight of the 19 team members were located on the company site in country A. The other 11 team members were located in a different company site in country B. The software developers in country B were not native speakers in the project's dominant language, but all team members in country A were. There was a variety in the language skills in the team in country B.

The subgroup manifests in the low number of interactions between the two team locations, but also in the perception of the team members, such as explained by one developer from country A:

"These people from the other location [country B] ... If there is not really anything, which has to be done together, we work rather isolated from each other. (System Architect 02_07)" 
The formation of this subgroup is mostly due to the difficulties to communicate informally by mail, phone or video chat. This hinders closer ties between team members and reduces trust and a shared understanding. One team member mentioned that it would be positive to meet the team members from the other location to get to know them on an informal basis:

"Yes, it is positive for the project when we meet in person from time to time and to see the person and not just hear the voice, or read their mails. (System Architect 02_11)"

This communication barrier not only leads to the separation of the team, but also intensifies the relationships within the two parts of the team. In team 2 , the projects dominant language is that of country A. The team members from country B often discuss the unclear issues first after the daily stand-up first internally and if this has not resolved the issue with a team member from country A:

"First of all, we try to clarify issues internally, and if there is any ambiguity, we'll get back to the [country A] team. (System Architect 02_11)'”

This communication barrier not only exists due to different countries, but also because of separate offices in team 1. The office with the physical scrum board is the dominant office and most of the discussions take place in this office. Team members from other offices have to actively seek being part of the discussion and not being cut off from the information flow. One member of team 1 describes this as followed:

"If you have two separate offices, discussions stay within one office. First, you ask others from the same office and this discussion is not passed on to the other office room (Software Developer 01_02)”

In team 1, the most dominant subgroup was formed due to previous ties between some of the team members. Most of these team members knew each other from previous projects, but there was also the case where two team members happened to have gone to secondary school together. It was usual for these team members to have lunch together with team members from the previous project, where they also discussed issues concerning the current project. The scrum master described this subgroup as follows:

"Yes, [we are a subgroup], definitely, it's quite normal. If you've already spent two years together, there is of course a different kind of relationship. (Scrum Master 01_04)"

The formation of this subgroup is mostly driven by the close relationships between the team members that know each other. A subgroup based on previous ties between some team members can also be found in team 2 , but it is only secondary due to the strong location based subgroup.

In team 2, we additionally find a strong task based subgroup. Normally, agile software development argues for a generalist approach, where every team member is theoretically responsible for every task. However, this team has been separated into technical consultants and into business consultants.

"You certainly have this [formation of a subgroup] between the technical consultants and the business consultants. (Scrum Master 02_09)"

\subsection{Traditional Method}

The two traditionally managed teams studied were well-established teams with motivated team members. We identified several faultlines and subgroups in each of the two teams. We report on them in table 4.

Similarly to the agile case, we find that demographic faultlines like age and gender are not activated in traditional method settings. Team 3 and 4 only had two females respectively and therefore, the formation of a gender based subgroup is unlikely. There is no strong age based faultline, because there was little variance in the age. Most of the people were between mid thirty and end forty, with one exception in team 3, where one member was 59 years old.

A knowledge based faultline is not activated, because people are assigned to a task based on their knowledge. Therefore, the dominant faultline is task.

A faultline based on function was not activated, although such a subgroup is likely in traditional methods due to the clear hierarchy. However, we did not find a strong hierarchical in the two analyzed teams and therefore no subgroups were formed.

We find that a faultline based on previous ties is not activated, because the team members are assigned to tasks and do not collaborate closely across tasks. Due to this, although there might be previous ties, they do not lead to the formation of a subgroup.

We find, that a task-based subgroup is the dominant subgroup, if traditional methods are used. Tasks in traditional methods are different from tasks in agile methods, because they take longer and, most of the time, people do the same task throughout the project. Therefore, the assignment to a task within a project with a traditional method separates the team and 
hinders close collaboration between the team members, which leads to the formation of subgroups. A member of team 3 describes this as follows:

"I mean, with people with whom you have relatively little to do, you have little exchange. With these, of course, you do not have this relationship on a personal level. (IT consultants 03_01)”,

Table 4. Theoretical and activated Faultlines

\begin{tabular}{|c|c|c|c|}
\hline 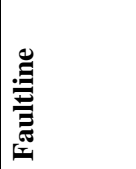 & & 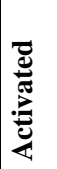 & 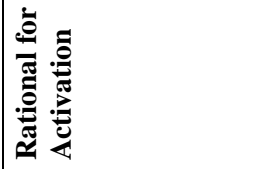 \\
\hline Age & $\begin{array}{l}\text { Team members were in } \\
\text { a similar age group. }\end{array}$ & & Little variance \\
\hline Gender & $\begin{array}{l}\text { Only small share of } \\
\text { team members were } \\
\text { female }\end{array}$ & & Not many females \\
\hline $\begin{array}{l}\text { Know- } \\
\text { ledge / } \\
\text { education }\end{array}$ & $\begin{array}{l}\text { Experts are assigned to } \\
\text { tasks based on their } \\
\text { knowledge }\end{array}$ & & $\begin{array}{l}\text { Task is the dominant } \\
\text { factor that leads to the } \\
\text { activation }\end{array}$ \\
\hline Function & $\begin{array}{l}\text { Clear hierarchies within } \\
\text { teams }\end{array}$ & & $\begin{array}{l}\text { We did not find a } \\
\text { hierarchical structure } \\
\text { to be present in the } \\
\text { teams }\end{array}$ \\
\hline $\begin{array}{l}\text { Previous } \\
\text { ties }\end{array}$ & $\begin{array}{l}\text { There are not many } \\
\text { previous ties }\end{array}$ & & \begin{tabular}{|l}
$\begin{array}{l}\text { People do not } \\
\text { collaborate closely } \\
\text { across tasks }\end{array}$ \\
\end{tabular} \\
\hline $\begin{array}{l}\text { Task / } \\
\text { goal }\end{array}$ & $\begin{array}{l}\text { Each team member has } \\
\text { a fixed task that does } \\
\text { not change }\end{array}$ & $\mathrm{X}$ & $\begin{array}{l}\text { Task-based subgroups } \\
\text { are formed }\end{array}$ \\
\hline $\begin{array}{l}\text { Geo- } \\
\text { graphical } \\
\text { distance }\end{array}$ & $\begin{array}{l}\text { Developers work in } \\
\text { different offices in } \\
\text { different countries. }\end{array}$ & $\mathrm{X}$ & $\begin{array}{l}\text { Informal contacts are } \\
\text { not possible }\end{array}$ \\
\hline Language & $\begin{array}{l}\text { Language is set to be } \\
\text { English, which is } \\
\text { known by both parties }\end{array}$ & $\mathrm{X}$ & $\begin{array}{l}\text { The mother tongue of } \\
\text { a large portion of the } \\
\text { team is German }\end{array}$ \\
\hline
\end{tabular}

Similarly to agile projects, we find that geographical distance and language are faultines that are activated and lead to the formation of subgroups.

"Two members working on this task are in Germany and the other two in India. There are, therefore, two subgroups which result from the geographical separation of the team. (IT consultant 04_02)“

In team 3 , we find that the team leader has decided that the team should have breakfast together every Monday. This team building effort has been introduced to implement a basis to exchange project related information across people that do not work on the same task.

\subsection{Comparison of Subgroups In Agile And Traditional Methods}

The results show that we find differences regarding subgroups between agile methods and traditional methods. Task-based subgroups are dominantly formed in projects with traditional methods. In agile projects, only temporary task-based subgroups are formed for the duration of specific user stories. This is due to the circumstance that tasks are different between the two methods. In traditional methods, tasks take longer and are over the entire term performed by the same persons. In agile methods however, tasks are shorter and performed by different combinations of people over time.

We find that previous ties leads to the formation of subgroups in agile methods, but not in traditional methods. In traditional methods, task-based subgroups are the dominant subgroup and separate the team into smaller parts that work on tasks. Previous ties are therefore only of minor relevance in traditional methods. Geographical distance as well as language are faultlines that are activated under traditional methods as well as under agile methods. Those are strong factors that divide the team members, because for instance it is hardly possible to build up an informal relationship with a person from another office location.

\section{Discussion}

\subsection{Theoretical and Practical Contribution}

Our results contribute to literature on agile and traditional methods. Vidgen and Wang [9] develop a framework that can be used to guide the organization of agile software development. However, their framework disregards the possible formation of subgroups. We extend the framework of Vidgen and Wang [9] by showing that subgroups play a role in agile software development. Our results show, that this is especially the case, when agile methods are violated. In one of the analyzed teams, the team was divided based on the kind of tasks that they had to perform. This has led to the formation of task-based subgroups. However, the division of the team based on types of tasks is not advised according to the principles of agile software development. Furthermore, geographical distance as well as language barriers lead to the formation of subgroups. As agile methods assume a colocated team, this violation leads to the formation of a subgroup. Therefore, Hossain, Babar [51] suggest that a scrum of scrum approach should be taken, if the team cannot be located in a single office space. 
We also contribute to literature on agile and traditional methods by showing that the formation of subgroups differs between agile and traditional methods. In traditional methods, the dominant factor for the formation of subgroups is the task. Team members that have different tasks hardly interact with each other.

In general, it seems that there are less strong and severe subgroups in projects with agile methods than in projects with traditional methods. Additionally, our results suggest that IT managers use approaches, like the breakfast in team 3 to decrease the effects of the strong subgroups.

Second, we contribute to literature on virtual teams $[46,47]$. We find that geographical distance as well as language leads to the formation of subgroups, no matter which type of development methodology is employed. This supports the claim of virtual teams literature that attributes like language and geographical distance can divide teams.

However, studies on virtual teams focus only on these attributes and mostly disregard subgroup theory [46]. For instance, Montoya-Weiss, Massey [52] analyzed conflict management in virtual teams, but did not consider literature on subgroups or faultlines, although they can be a source for conflicts within teams [7, 53]. Oshri, Van Fenema [54] analyze knowledge transfer within virtual teams, but do not consider that the flow of information is influenced by the subgroups within the team [55]. Theory on subgroups and faultlines could give these studies an alternative perspective.

This perspective has already been employed by studies on virtual teams in non IT settings $[18,48]$. We extend this to the IT domain. Furthermore, only considering geographical distance or cultural aspects as factors disregards the broader picture. We find that previous ties in agile projects and the task assignment in projects with a traditional method do additionally have an influence.

Third, we contribute to the limited research on faultlines and subgroups in the IT domain. We show that identity-based factors like gender and age do not lead to the formation of subgroups. This is opposed to previous findings in other domains $[56,57]$. We do not find support that identity-based factors like gender and age lead to the formation of subgroups. Our results suggest that this is caused by the nature of the IT section. As females are still underrepresented in ITteams, there were not enough representatives to build this form of subgroups. Women are rather integrated in the whole team and get included in other subgroups that are independent from gender. Similarly, the age structure was balanced, which hindered the formation of age-based subgroups.
We contribute to practice by outlining which factors lead to the formation of subgroups in projects with agile methods and in projects with traditional methods. Subgroups within project teams are an issue in practice, because they influence the way how the team members interact and communicate with each other [11]. Due to this the performance of the project is also affected by the existence of subgroups within the team [10-13].

There are several ways how IT project managers can address the subgroups and faultlines in their teams. For instance, they can conduct team building efforts before the start of the project. Especially in the case of a project with several sites, it is advisable that the whole team has the possibility to informally exchange and get to know each other due to the strong subgroups based on geographical distance that we have identified.

\subsection{Limitations}

First, our results are limited by the circumstance, that we did not interview all members of the team. As subgroups might be perceptional [28], it is possible that we have missed certain subgroups. However, we interviewed quite a large share of the groups, which makes it unrealistic that we missed large or strong subgroups. Second, the analyzed teams differ in size and organizational context. Due to this, it is possible that we found subgroups that are not related to the project management method, but to the setting of the project. Third, we only analyzed two project teams with agile methods and two project teams with traditional methods. Due to this limited number, it is possible that we missed subgroups that are relevant, but were not present in our cases.

\subsection{Future Research}

We only analyzed four teams from two different firms. Due to this limited setting, it was not possible to analyze the influence of different contexts on the formation of subgroups in detail. However the context could have a huge influence on the activation of certain faultlines. Future research could further address which faultlines dominate others and whether these could be affected by management practices. Studies could examine how far agile methods could reduce locationbased faultlines in distributed teams in detail.

The size of the teams that we analyzed has been between 12 and 19. Future research could address this by varying the team size. Due to closer collaboration in smaller teams, it could be the formation of subgroups differs. It could be the case that task-based subgroups do not form in traditional projects, because a specific 
task is assigned to only one person and not to several. The formation of subgroups could also be different in larger teams. Subgroups, based on special competencies of certain team members [58], could form in large teams.

Up to now, we have only analyzed Scrum as a representative of agile project management methods. Future research could address other ones. For instance, the formation of Subgroups could differ in Pair Programming due to the close collaboration between two team members.

Another possible area for future research could be related to the question how subgroups are resolved in agile methods and in traditional methods. We have found that team 3 has breakfast together every Monday. One could analyze whether such teambuilding events are effective in resolving subgroups. Approaches to resolve subgroups could have different influences in agile and traditional projects. An event to get to know all team members might be useful in a traditional project, but not in an agile project with Scrum, because all team members know each other from the daily stand-up meeting.

\section{Conclusion}

This paper was motivated by a need to understand groups within agile and traditional IT projects. The results of the conducted case studies show that the formation of subgroups differs between the two types of projects. We find that previous ties leads to the formation of subgroups in agile methods whereas task assignment leads to strong subgroups in traditional methods.

\section{Acknowledgment}

We thank the German Federal Ministry for Economic Affairs and Energy for funding this research as part of the project 01MD15001D (ExCELL). We also thank the interviewees for their valuable insights.

\section{References}

[1] Faraj, S. and Sproull, L., "Coordinating expertise in software development teams", Management science, 46(12), 2000, p. 1554-1568.

[2] Tanaka, K., Morimoto, C., Fujita, Y., and Tsuda, K., "The optimal configuration method of software engineer to IT project", International Journal of Computer Applications in Technology, 52(2/3), 2015, p. 177-185.
[3] Mathieu, J.E., Tannenbaum, S.I., Donsbach, J.S., and Alliger, G.M., "A review and integration of team composition models: Moving toward a dynamic and temporal framework", Journal of Management, 40(1), 2014, p. 130-160.

[4] Hoffman, L.R. and Maier, N.R., "Quality and acceptance of problem solutions by members of homogeneous and heterogeneous groups", The Journal of Abnormal and Social Psychology, 62(2), 1961, p. 401.

[5] Tiwana, A. and Mclean, E.R., "Expertise integration and creativity in information systems development", Journal of Management Information Systems, 22(1), 2005, p. 13-43.

[6] Gibson, C. and Vermeulen, F., "A healthy divide: Subgroups as a stimulus for team learning behavior", Administrative Science Quarterly, 48(2), 2003, p. 202239.

[7] Carton, A.M. and Cummings, J.N., "A Theory of Subgroups in Work Teams", Academy of Management Review, 37(3), 2012, p. 441-470.

[8] Brhel, M., Meth, H., Maedche, A., and Werder, K., "Exploring principles of user-centered agile software development: A literature review", Information \& Software Technology, 61, 2015, p. 163-181.

[9] Vidgen, R. and Wang, X., "Coevolving systems and the organization of agile software development", Information Systems Research, 20(3), 2009, p. 355376.

[10] Bezrukova, K., Jehn, K.A., Zanutto, E.L., and Thatcher, S.M.B., "Do Workgroup Faultlines Help or Hurt? A Moderated Model of Faultlines, Team Identification, and Group Performance", Organization Science, 20(1), 2009, p. 35-50.

[11] Bezrukova, K., Thatcher, S.M.B., Jehn, K.A., and Spell, C.S., "The Effects of Alignments: Examining Group Faultlines, Organizational Cultures, and Performance", Journal of Applied Psychology, 97(1), 2012, p. 77-92.

[12] Carton, A.M. and Cummings, J.N., "The Impact of Subgroup Type and Subgroup Configurational Properties on Work Team Performance", Journal of Applied Psychology, 98(5), 2013, p. 732-758.

[13] Meyer, B., Glenz, A., Antino, M., Rico, R., and González-Romá, V., "Faultlines and Subgroups: A Meta-Review and Measurement Guide", Small Group Research, 45(6), 2014, p. 633-670.

[14] Lau, D.C. and Murnighan, J.K., "Demographic Diversity And Faultlines: The Compositional 
Dynamics Of Organizational Groups", Academy of Management Review, 23(2), 1998, p. 325-340.

[15] Tripp, J.F., Riemenschneider, C., and Thatcher, J.B., "Job Satisfaction in Agile Development Teams: Agile Development as Work Redesign", Journal of the Association for Information Systems, 17(4), 2016, p. 267-307.

[16] Whitworth, E. and Biddle, R. "The Social Nature of Agile Teams". in Agile Conference (AGILE), 2007. 2007.

[17] Lau, D.C. and Murnighan, J.K., "Interactions Within Groups and Subgroups: The Effect Of Demographic Faultlines", Academy of Management Journal, 48(4), 2005, p. 645-659.

[18] Polzer, J.T., Crisp, C.B., Jarvenpaa, S.L., and Kim, J.W., "Extending the faultline model to geographically dispersed teams: How colocated subgroups can impair group functioning", Academy of Management Journal, 49(4), 2006, p. 679-692.

[19] Dau, L.A., "Biculturalism, Team Performance, and Cultural-faultline Bridges", Journal of International Management, 22(1), 2016, p. 48-62.

[20] Carton, A.M. and Cummings, J.N., "A Theory, Measure, and Empirical Test of Subgroups in Work Teams", Academy of Management Review, 37(3), 2012, p. 441-470.

[21] Hinds, P.J., Neeley, T.B., and Cramton, C.D., "Language as a Lightning Rod: Power Contests, Emotion Regulation, and Subgroup Dynamics in Global Teams", Journal of International Business Studies, 45(5), 2014, p. 536-561.

[22] Sawyer, J.E., Houlette, M.A., and Yeagley, E.L., "Decision Performance and Diversity Structure: Comparing Faultlines in Convergent, Crosscut, and Racially Homogeneous Groups", Organizational Behavior and Human Decision Processes, 99(1), 2006, p. 1-15.

[23] Ellis, A.P.J., Mai, K.M., and Christian, J.S., "Examining the Asymmetrical Effects of Goal Faultlines in Groups: A Categorization-Elaboration Approach", Journal of Applied Psychology, 98(6), 2013, p. 948-961.

[24] Rico, R., Molleman, E., Sanchez-Manzanares, M., and Van der Vegt, G.S., "The Effects of Diversity Faultlines and Team Task Autonomy on Decision Quality and Social Integration", Journal of Management, 33(1), 2007, p. 111-132.

[25] Cooper, D., Patel, P.C., and Thatcher, S.M., "It Depends: Environmental Context and the Effects of
Faultlines on Top Management Team Performance", Organization Science, 25(2), 2013, p. 633-652.

[26] Jehn, K.A. and Bezrukova, K., "The faultline activation process and the effects of activated faultlines on coalition formation, conflict, and group outcomes", Organizational Behavior and Human Decision Processes, 112(1), 2010, p. 24-42.

[27] Hogg, M.A. and Terry, D.J., "Social Identity and Self-Categorization Processes in Organizational Contexts", The Academy of Management Review, 25(1), 2000, p. 121-140.

[28] Homan, A.C., Van Knippenberg, D., Van Kleef, G.A., and De Dreu, C.K.W., "Bridging Faultlines by Valuing Diversity: Diversity Beliefs, Information Elaboration, and Performance in Diverse Work Groups", Journal of Applied Psychology, 92(5), 2007, p. 1189-1199.

[29] Esses, V.M., Jackson, L.M., and Armstrong, T.L., "Intergroup Competition and Attitudes Toward Immigrants and Immigration: An Instrumental Model of Group Conflict", Journal of Social Issues, 54(4), 1998, p. 699-724.

[30] Blau, P.M., "Inequality and heterogeneity: A primitive theory of social structure". Vol. 7. 1977: Free Press New York.

[31] Cramton, C.D. and Hinds, P.J., "Subgroup Dynamics in Internationally Distributed Teams: Ethnocentrism or Cross-National Learning?", Research in Organizational Behavior, 26, 2004, p. 231-263.

[32] Sawyer, J.E., Houlette, M.A., and Yeagley, E.L., "Decision performance and diversity structure: Comparing faultlines in convergent, crosscut, and racially homogeneous groups", Organizational Behavior \& Human Decision Processes, 99(1), 2006, p. $1-15$.

[33] Meyer, B., Schermuly, C.C., and Kauffeld, S., "That's not my place: The interacting effects of faultlines, subgroup size, and social competence on social loafing behaviour in work groups", European Journal of Work \& Organizational Psychology, 25(1), 2016, p. 31-49.

[34] Meyer, B., Shemla, M., Li, J., and Wegge, J., "On the Same Side of the Faultline: Inclusion in the Leader's Subgroup and Employee Performance", Journal of Management Studies, 52(3), 2015, p. 354380 .

[35] Scrum Alliance, "2016 State of Scrum Report How the world is successfully applying the most popular Agile approach to projects ". 2017. 
[36] Moe, N.B., Dingsøyr, T., and Dybå, T., "A teamwork model for understanding an agile team: A case study of a Scrum project", Information and Software Technology, 52(5), 2010, p. 480-491.

[37] Acuña, S.T., Gómez, M., and Juristo, N., "How do personality, team processes and task characteristics relate to job satisfaction and software quality?", Information \& Software Technology, 51(3), 2009, p. 627-639.

[38] Moe, N.B., Aurum, A., and Dybå, T., "Challenges of shared decision-making: A multiple case study of agile software development", Information \& Software Technology, 54(8), 2012, p. 853-865.

[39] Alzoubi, Y.I., Gill, A.Q., and Al-Ani, A., "Empirical studies of geographically distributed agile development communication challenges: A systematic review", Information \& Management, 53(1), 2016, p. 22-37.

[40] Beck, K., Beedle, M., van Bennekum, A., Cockburn, A., Cunningham, W., Fowler, M., Grenning, J., Highsmith, J., Hunt, A., Jeffries, R., Kern, J., Marick, B., Martin, R., Mallor, S., Shwaber, K., and Sutherland, J. The Agile Manifesto. 2001; Available from: http://agilemanifesto.org.

[41] Espinosa, J.A., Nan, N., and Carmel, E., "Temporal Distance, Communication Patterns, and Task Performance in Teams", Journal of Management Information Systems, 32(1), 2015, p. 151-191.

[42] Ghobadi, S. and Mathiassen, L., "A Model for Assessing and Mitigating Knowledge Sharing Risks in Agile Software Development", Information Systems Journal, 2016, p.

[43] Leffingwell, D., "Agile software requirements: lean requirements practices for teams, programs, and the enterprise". 2010: Addison-Wesley Professional.

[44] Persson, J.S., Mathiassen, L., and Aaen, I., "Agile distributed software development: enacting control through media and context", Information Systems Journal, 22(6), 2012, p. 411-433.

[45] Ramesh, B., Cao, L., Mohan, K., and Xu, P., "Can distributed software development be agile?", Communications of the ACM, 49(10), 2006, p. 41-46.

[46] Gilson, L.L., Maynard, M.T., Jones Young, N.C., Vartiainen, M., and Hakonen, M., "Virtual teams research: 10 years, 10 themes, and 10 opportunities", Journal of Management, 41(5), 2015, p. 1313-1337.

[47] Ale Ebrahim, N., Ahmed, S., and Taha, Z., "Virtual teams: A literature review", 2009, p.
[48] O'Leary, M.B. and Mortensen, M., "Go (con) figure: Subgroups, imbalance, and isolates in geographically dispersed teams", Organization Science, 21(1), 2010, p. 115-131.

[49] Yin, R.K., "Case study research: Design and methods". 2013: Sage publications.

[50] Wiesche, M., Jurisch, M., Yetton, P., and Krcmar, H., "Grounded Theory Methodology in Information Systems Research", MIS Quarterly, 43(3), 2017, p. 685-701.

[51] Hossain, E., Babar, M.A., and Paik, H.-y. "Using scrum in global software development: a systematic literature review". in Global Software Engineering, 2009. ICGSE 2009. Fourth IEEE International Conference on. 2009. Ieee.

[52] Montoya-Weiss, M.M., Massey, A.P., and Song, M., "Getting it together: Temporal coordination and conflict management in global virtual teams", Academy of management Journal, 44(6), 2001, p. 1251-1262.

[53] Pelled, L.H., Eisenhardt, K.M., and Xin, K.R., "Exploring the black box: An analysis of work group diversity, conflict and performance", Administrative science quarterly, 44(1), 1999, p. 1-28.

[54] Oshri, I., Van Fenema, P., and Kotlarsky, J., "Knowledge transfer in globally distributed teams: the role of transactive memory", Information Systems Journal, 18(6), 2008, p. 593-616.

[55] Ellis, A.P., Hollenbeck, J.R., Ilgen, D.R., Porter, C.O., West, B.J., and Moon, H., "Team learning: Collectively connecting the dots", Journal of Applied Psychology, 88(5), 2003, p. 821.

[56] De Meulenaere, K., Boone, C., and Buyl, T., "Unraveling the impact of workforce age diversity on labor productivity: The moderating role of firm size and job security", Journal of Organizational Behavior, 37(2), 2016, p. 193-212.

[57] Yunhyung, C., Hui, L., Jackson, S.E., Subramony, M., Colakoglu, S., and Yuan, J., "Cracking But Not Breaking: Joint Effects Of Faultline Strength And Diversity Climate On Loyal Behavior", Academy of Management Journal, 58(5), 2015, p. 1495-1515.

[58] Wiesche, M. and Krcmar, H. "The relationship of personality models and development tasks in software engineering". in Proceedings of the 52nd ACM conference on Computers and people research. 2014. ACM. 